\section{THE UNVEILING OF A STATUE OF PRIESTLEY AT BIRSTALL.}

THE merits of Joseph Priestley-theologian, 1 philosopher, social reformer, and man of science-were recognised by some at least of his contemporaries. He was on terms of friendship with such men as Franklin, Wedgwood, Watt, and Banks, and he enjoyed the patronage and companionship of Lord Shelburne. In 1766 he was elected a fellow of the Royal Society, and seven years later the Copley medal was awarded to him.

To many of his fellow-countrymen, on the other hand, Priestley was but a violent and obstinate schismatic, intent only on undermining the established order of things. It was indeed the intolerant and cruel expression of this view by the Birmingham mob that led him to emigrate to the United States in the sixty-second year of his age.

Such clouds, however, as once obscured Priestley's fair fame have now entirely passed away, and the services which he rendered to the national life, whether as a pioneer of chemical science or as an "honest heretic," are everywhere recognised. Public memorials of the man and his work have been erected in Birmingham, Warrington, and Leeds, and recently another has been added to the number. For the citizens of Birstall, in the West Riding, where Priestley was born in 1733, have combined, with praiseworthy public spirit and enthusiasm, to erect a statue of their eminent townsman.

This latest memorial was unveiled on October 12 by Sir Edward Thorpe, whose ready pen has materially contributed to a just appreciation of Priestley's character and work by this generation. The ceremony was performed in presence of a large and distinguished company, and general satisfaction was expressed at the manner in which the scheme for commemorating Birstall's most famous son had been brought to a successful issue.

After the unveiling ceremony, the company adjourned to the Temperance Hall, where an address was delivered by Sir Edward Thorpe. In an illuminating review of Priestley's life and the various factors that shaped his career, emphasis was laid on the influence of his early environment. From his sixth year onward Priestley was entrusted to the care of his aunt, Mrs. Keighley, a worthy, intelligent, and broad-minded woman, to whose house the cultured people of the neighbourhood were wont to resort. For a time ill-health prevented the boy attending school with regularity, and to a large extent he had to make his way to knowledge unaided. These circumstances, cooperating with his natural keenness and diligence, developed in young Priestley that mental activity and independence which later were characteristic of his attitude towards theological, philosophical, political, and social questions.

After a suitable training Priestley entered the ministry, and worked successively at Needham, Nantwich, and Warrington. It was not until he went to Leeds in 1767 that he began those No. 2244 , VOL. 90$]$ chemical investigations on which his fame chiefly rests. It is indeed remarkable, as Sir Edward Shorpe pointed out, that a man like Priestley, without previous training, with domestic utensils for his apparatus and tallow candles for his source of heat, should have made the great discoveries in pneumatic chemistry with which his name is associated.

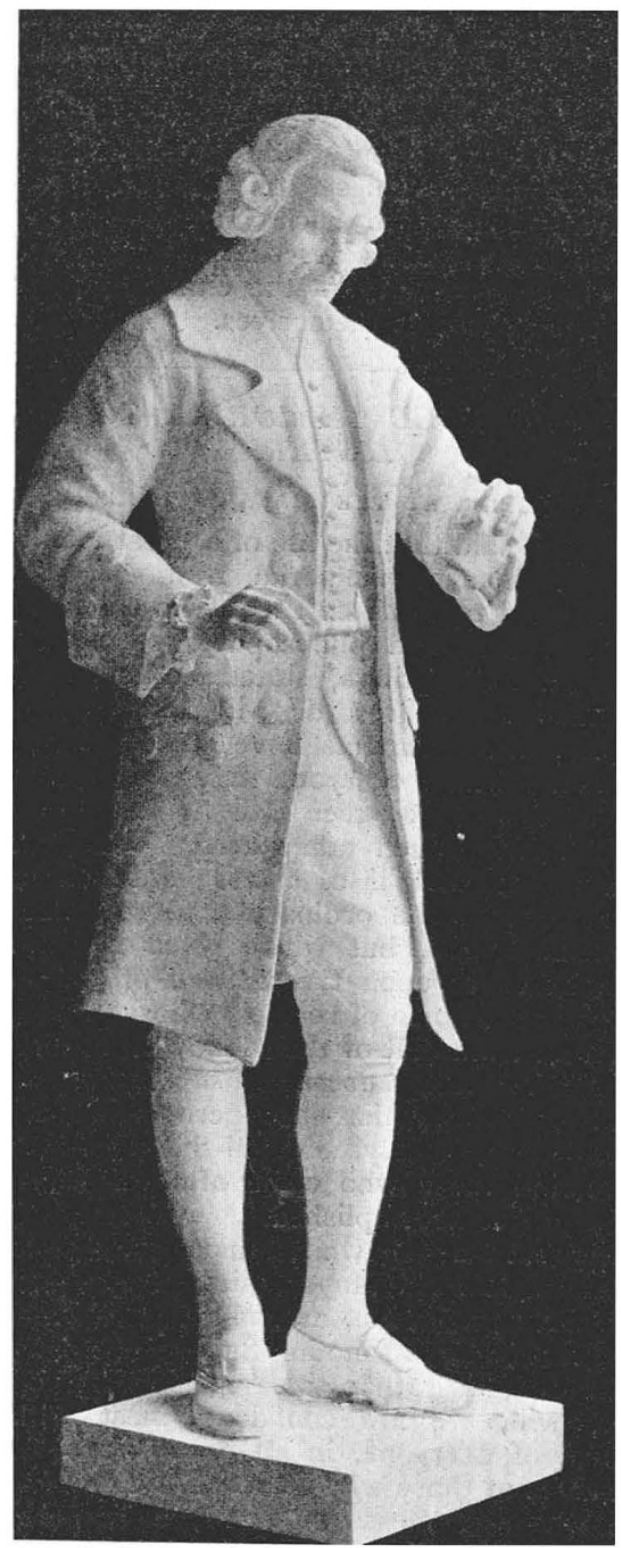

The Priestley Statue at Birstall. Sculptor: Miss Darlington.

It was, however, during his seven years at Calne, in Wiltshire, under the patronage of Lord Shelburne, that Priestley's best experimental work was done. It must be admitted that he did not at all realise the true significance of his investigations. The discovery of oxygen was destined to revolutionise chemical science, and yet Priestley himself, to the end of his days, 
clung to the antiquated conceptions which his own experiments had really overthrown. In this connection Sir Edward Thorpe has emphasised the striking contrast between Priestley the social, political, and theological reformer, always in advance of his time, and Priestley the conservative and orthodox man of science.

Sir Edward holds that, great as was Priestley's merit as an experimentalist, a greater claim to our regard rests on his struggrles and sufferings in the cause of liberty. Unpopularity and even persecution were his lot during his later years in England, and it is to Priestley's everlasting credit that he did not allow these untoward circumstances to disturb his serene and genial temper. In paying tribute to such a man-one whom Frederic Harrison has described as "the hero of the eighteenth century "--the citizens of Birstall have done honour to themselves. J. C. P.

\section{THE PROPOSED MEMORIAL TO LORD LISTER.}

\section{Meeting at the Mansion House,}

[ $T$ may be said that the life of a great man needs 1 no permanent memorial from his contemporarics, and to some extent this is true. Poets, men of letters, and philosophers speak to posterity in their writings, statesmen and warriors have their deeds recorded in history, artists, sculptors, and architects have erected their own monuments which everyone may see. Yet even to them their fellow-men delight to raise some special token of their admiration. But there are others whose work is of a less public character, less obvious to the ordinary observer, and less easily understood, but which often has a more important effect upon the welfare of the world. Of such are the men of science, whose atmosphere is different from that of their fellow-men, and who occupy the edita doctrina sapientum templa serena. It is fitting that some permanent memorial should from year to year recall the names of such and remind those who come after of what it is that they have accomplished.

The great meeting which, under the auspices of the venerable Lord Mayor, himself a member of the medical profession, assembled at the Mansion House last week to sanction the project for raising a memorial, or rather some memorials, to Lord Lister, will, we are confident, meet with the approval of everyone, in all parts of the world. The names of those who attended the meeting and those who sent messages of regret at being unable to do so, indicate how wide is the sympathy that it has aroused. Statesmen, ecclesiastics, soldiers, representatives of science and of medicine, of the City companies, of hospitals, and of the general public were all enthusiastic in their commendation of the scheme. Such evidence reminds us that Lister's work was not merely one which revolutionised surgical practice, and was thus instrumental in saving his fellow-creatures from premature death and unnecessary suffering, and enabled the art of surgery to advance NO. 2244, vOL. 90] by leaps and bounds to a degree undreamt of before; but that its scientific value alone is so great as to justify his being placed amongst the most distinguished men of this or any other age.

The Lord Chancellor, in the unavoidable absence of the Prime Minister, paid an eloquent tribute to Lister's pre-eminence and to the far-reaching effects of his doctrines; yet the man in the street has but little notion of the benefits he has derived from them; he has perhaps learned the two words "antiseptic system," but they convey no meaning to him; and he does not appreciate the dangers which have been averted and the sorrows prevented for him and those who are dearest to him. It is for these that a speaking memorial should be raised, and it is from these, if they can be made to understand its meaning, that we feel sure an appeal for the necessary funds will not be made in vain.

A very influential committee has been formed of representatives of all classes in the United Kingdom and the Colonies and of Ambassadors and Ministers of foreign countries, and in their opinion it is fitting that whatever is done should partake not only of a national, but an international character. This committee, after careful consideration, submitted a scheme to the Mansion House meeting, which met with cordial approval.

The Dean of Westminster, who is a warm sympathiser with it, desired that Lord Lister's ashes should find their final resting-place in Westminster Abbey, but owing to his own very strict injunctions concerning his funeral, this could not be carried out. It is proposed, therefore, that a medallion with a suitable inscription should be placed in the north aisle near those of Darwin and other eminent men of science that cluster round the monument of Newton. Westminster Abbey is an international institution, and it is certain that this proposal will not appeal to Englishmen alone.

It is also thought that everyone will be in favour of the erection of a sculptured monument, not a mere statue, but something which will direct attention to the nature of his achievements, in some prominent place in London which every citizen and every visitor cannot fail to see and to observe.

But it was felt that a memorial of a still more international character was desirable, and for that the committee recommended something which would combine the merits of the Nobel Prize and those of the Carnegie Trust. Under the proposed scheme the trustees of the fund would be able to devote the interest of it at their discretion either to the promotion of research bearing upon the progress of surgery, or as awards in recognition of notable advances in this science. Naturally these awards would be open to men of all nations, and this is as it should be, for Lister's work was not in any sense insular; its beneficent effects are felt in every part of the inhabited world.

We think that the decisions of the committee are wise and will meet with general approval. It is needless to say that in order to carry them out a large sum of money will be required. We are happy to hear that already several generous donations have been made, and we have great 